UDC 37.02

Iryna Liashenko

Education \& Research Institute for Business Technologies "UAB"

Sumy State University

ORCID ID 0000-0003-4211-5116

DOI 10.24139/2312-5993/2019.07/081-090

\title{
DISCIPLINARY LTERACY DEVELOPMENT AS THE CORE STANDARD OF EDUCATION
}

Modern requirements to the quality of education require continuous improvement of approaches to the search for optimal learning. There has been a growing trend in communication development and a decrease in the quality of student acquisition of material for recent years. Modern education focuses on the development of general skills, but on the other hand, the modern education system does not emphasize development of special skills, which are aimed at basic skills. This paper examines the concept of disciplinary literacy, which is intended to deepen the learning process in order to harmonize the work of all common components on the need for specific skills not only for future professional situations, but also for everyday social and cultural surrunding. The work gives a literary review of disciplinary literacy in the learning process.

Key words disciplinary literacy, literacy, development of special skills, general skills, strategies for development of disciplinary literacy.

Introduction. Lately, increasing growth of society has been developing new requirements for the skills necessary for efficient grasping of new information, particularly for specific purposes. Modern skills of the $21^{\text {st }}$ century count a range of abilities and capacities, among which the basic skills of reading, writing, inquiring and analyzing. When the school gives the common knowledge about how to work with information, disciplinary literacy aims to acquire the information purposefully, being aware of following it with analyzing and applying.

Analysis of the literature on this topic has proved the necessity to improve the rigor in developing disciplinary literacy. The term "literacy" is defined not only as an ability to read and to write, to be literate, but in the modern context it means a wider ability to be more specific in application, such as "a set of multi-faceted social practices that are shaped by contexts, participants, and technologies" (Archibald et al., 2011). According to the educational research, the progress in learning, particularly in reading and taking the national tests, is diminishing every year (Grigg et al., 2007; Kirsch et al., 2002).

Disciplinary literacy is defined in the study of Moje (2007) as the "...approach to teaching and learning that integrates academically rigorous content with discipline-appropriate habits of thinking. The driving idea is that knowledge and thinking must go hand in hand. To develop deep conceptual knowledge in a discipline, one needs to use the habits of thinking that are 
valued and used by that discipline. To develop strategic and powerful discipline-specific habits of thinking, one needs to be directed by one's content knowledge. For students to become literate in a particular discipline, they must grow in both dimensions simultaneously. The ultimate goal of Disciplinary Literacy is that all students will develop deep content knowledge and literate habits of thinking in the context of academically rigorous learning in individual disciplines" (M oje, 2007).

Disciplinary literacy is becoming very important in our media fast growing society. The analyzed literature and documents present difficulties for the students. These texts often contain summaries, drawings, tables, diagrams and specialized vocabulary. Ideas are complex and are based on many points that require attention and strategic work. To understand and process this type of text students should be immersed in the content and thinking processes of this discipline and be supported by an expert, their teacher (Evers, 2011).

We support the definition of disciplinary literacy which reveals the main ideas of its context: "disciplinary literacy is defined as the confluence of content knowledge, experiences, and skills merged with the ability to read, write, listen, speak, think critically and perform in a way that is meaningful within the context of a given field" (Evers, 2011). Disciplinary literacy is becoming one of the key skills in the 21st century for developing specialized knowledge which is relevant to each subject area, further professional preparation and to any sphere of life (Zygouris-Coe, 2012). As this quality is becoming more and more actual in modern education, we develop the research analyzing and reviewing the main concepts of this skill.

Analysis of relevant research. The main idea of the term "disciplinary literacy" (DL) is that the main skills, such as reading, writing, thinking, reasoning and doing are completed to specify the exact discipline - to define how each sphere of life creates, evaluates and assesses knowledge differently (Lent, 2015:1). Each discipline has its own literacy skills based on the type of discipline, key concepts, language, vocabulary, common textual structures, and textual properties, as well as subject-specific reading and writing subjects. Understanding these different reading and writing skills is not only important to building knowledge in the discipline but also to think critically about the information presented. In addition to effective reading and writing, students need to learn from knowledgeable practitioners to think about how knowledge is generated and produced in each discipline. How does it relate to the previous training? And how to rate ideas about relevance, reliability, and reliability. The factors associated with effective learning across disciplines differ in the focus and intensity with which they are used to read, think, and write content.

DL has become wider in meaning and adds specific content skills for each area. Thus, disciplinary literacy in visual arts consists of reading, writing, listening, thinking, speaking, and performing (Hillman, 2014). A student, who is 
engaged in painting, has a necessary component in this set as painting, so, the main skills work for painting as a specific professional goal.

Aim of the study. In view of analyzed definitions of content-based learning, it has become obvious that disciplinary literacy is the deeper and further development of efficient education according to the modern standards of recent requirements of a dynamic society. Thus, in this study, we continue researching the definition of disciplinary literacy. The objectives of this study are to define the disciplinary literacy, to review recent research into the importance of disciplinary literacy and to provide a conceptual theoretical framework based on the structure of disciplinary literacy.

Research methods. To achieve the goal, confirmation of the hypothesis and fulfillment of the research tasks, a complex of modern theoretical methods of research and approaches was used: analysis, synthesis, induction, deduction, systematization, comparison, generalization, which allowed developing scientific sources, determining the essence and features of disciplinary literacy, justifying the advantages and shortcomings.

Research results. To define the term disciplinary literacy, we reviewed the number of studies in this sphere.

Disciplinary literacy is suggested as an ability to acquire a construct of basic skills, such as reading, writing, speaking, analyzing within the specific discipline.

Shanahan and Shanahan (2008) have proposed a model of reading development summarized in three phases:

Basic literacy - learning to decode words, develop a reading vocabulary, and comprehend text.

Intermediate literacy - using general strategies for decoding longer words and comprehending narrative and expository text.

Disciplinary literacy - using specialized strategies for comprehending and responding to texts that reflect the demands of a specific discipline (Shanahan, $\&$ Shanahan, 2008). DL is argued to be one of the advanced literacy instruction which arises from basic literacy into a specific one. There may be no pure phase in this model: students may demonstrate two phases at the same time, or even three - it depends on their interests, background, and capacities.

Disciplinary literacy may be erroneously substituted by content literacy. The difference is that content literacy deals with the techniques which develop the initial knowledge in the specific area, whereas disciplinary literacy emphasizes the unique tools for professional, deep engaging in the discipline (Shanahan, \& Shanahan, 2012). Content-area literacy refers to an initial set of techniques for reading and understanding texts for determining important information, making inferences, asking questions, and summarizing in different types of content. Disciplinary literacy involves specific information, specialized vocabulary, expertise critical responding to produce and communicate each 
specific knowledge given in the texts. It is suggested that disciplinary literacy is a highly developed skill, as shown in Table 1 (Lent, 2015).

Table 1

The connection between deeper learning and disciplinary literacy

\begin{tabular}{|l|l|}
\hline \multicolumn{1}{|c|}{ Deeper Learning } & \multicolumn{1}{|c|}{ Disciplinary Literacy } \\
Results in the mastery of core academic & $\begin{array}{l}\text { Results in the mastery of core academic } \\
\text { content by developing expertise in specific } \\
\text { disciplines }\end{array}$ \\
\hline $\begin{array}{l}\text { Application: Students master content by engaging in the habits of thinking and "work" of the } \\
\text { discipline }\end{array}$ & $\begin{array}{l}\text { Employs critical thinking and problem solving } \\
\text { by engaging in the methods and inquiries of } \\
\text { a discipline }\end{array}$ \\
\hline $\begin{array}{l}\text { Employs critical thinking and problem solving } \\
\text { specific problems }\end{array}$ & $\begin{array}{l}\text { Relies on collaboration within the classroom } \\
\text { community that mirrors the work done by } \\
\text { those in the field }\end{array}$ \\
\hline Relies on collaboration &
\end{tabular}

Application: Students learn how to become self-directed within a team as they plan, share, and assess learning within a discipline

Fosters an academic mindset within a discipline mindset by learning and experiencing the foundational facts, skills, norms, and habits

Application: Students find meaning as it relates to the discipline as they wrestle with project plans, disciplinary principles, and demonstrations of learning

Is supported through communication in Is supported through communication in writing and speaking writing and speaking as discipline-specific tools for engaging in the work of the discipline

Application: Students learn how to use writing and speaking as they act as apprentices in a given discipline

Through a disciplinary approach to literacy, students use the ability to engage in goals and practices that are unique to any academic discipline. The students use discipline-specific frameworks for completing the critical tasks: 1) interpreting texts and 2) composing and revising texts. The main action verbs used in DL approach instructions are "evaluate, determine, annotate, identify, discuss, suggest" (International Literacy Association, 2017).

Disciplinary literacy allows moving from the limited content-area strategies and clarifies how teachers can teach in a more effective way. Apart from the varied ways that students read, reason, write, think, speak, it respects also an ability to participate in specific content areas (Lent, 2015).

Disciplinary literacy is defined as a multidimensional construct with at least three disciplinary literacies: source literacy, analytic literacy, and expressive literacy in the set of four main disciplines at secondary school (Spires et al., 2017). 
Moje (2007) suggests that disciplinary literacy approach to the studying requires analytical and critical thinking about the specific context. Thus, history educators apply DL approach to define the questions of purpose, evidence, chromoly, causality, and contexts. Discipline literacy in science practices prediction, observation, analysis, summarization, and presentation to their science reading. More than that, the scientists predict explanations for phenomena, hypothesize, design and enter the results of investigations and conclude the results. In studying English Arts except of reading skills the skills on interpreting, recognizing the literary devices and structures are used (M oje, 2007).

Disciplinary literacy has been defined as "the use of reading, reasoning, investigating, speaking, and writing required to learn and form complex content knowledge appropriate to a particular discipline" (McConachie \& Petrosky, 2010:6).

DL does not only focus on the similar features of literacy in the content area but highlights the differences in the specific features of the discipline.

It is also suggested that disciplinary literacy of functional linguistics consists not only of grammar itself but also of considering contextualized and practical uses of language, making it useful for considering differences across discipline (Halliday et al., 2014).

$\mathrm{DL}$ is defined as the ability to be involved in social, semiotic, and cognitive practices consistent with the content experts. It is suggested, that literacy instruction in academic disciplines should move beyond the time-honored focus on basic skills (e.g., vocabulary, fluency), general cognitive strategies (e.g., predicting, inferencing), and related learning strategies (e.g., highlighting, notetaking) to include an emphasis on discipline-specific practices that promote simultaneous engagement with disciplinary language and disciplinary content (Fang, 2012).

So, $\mathrm{DL}$ is developing if it arises in meaningful, engaging, and challenging activities, which can help deeply and consciously attain the specific goal. In this case, the strategies for such development should include collaboration with peers (Lent, 2015).

One of the studies argues that the work of the university department consists of four scholarships: discovery, integration, application, and teaching. The latter is translated as a pedagogical scholarship and science. Teaching, in this case, should be grounded in the work of others. Moreover, knowledge about teaching should be shared, peer-reviewed, critiqued and published. So, there should be a natural amount of collaboration in higher education: what in the whole makes disciplinary literacy in this area (Airey, 2011).

For practical development of disciplinary literacy, the educational researchers suggest a number of strategies which are closely connected with critical inquiry and analyzing. For example, for reading activities the main key actions for activation the disciplinary literacy may be: "provide ongoing, 
embedded literacy professional learning", "form a literacy leadership team", "make sure professional learning communities or disciplinary literacy cohorts are grounded in continuous disciplinary literacy leaning and collaborative inquiry", "provide the resources", "ensure that teachers, especially those in cohorts or teams, experience encouragement, support, and opportunities to stretch their skills and knowledge", "encourage cross-curricular or cross-team collaboration", "foster leadership in all areas", "use reflection, learning, and planning collaboratively", "find opportunities for co-teaching and peer coaching within disciplines" (Lent \& Voigt, 2018).

There also the techniques for evaluating the speaker's thinking process, which are designed to inquire and deeply understand the specific content, necessary within the discipline. They might be these:

1. What is the purpose of the talk or interview?

2. Why was this speaker chosen to speak on the topic?

- What are his or her credentials?

- In what way is he or she an expert in the field?

3. How did this speaker's thoughts differ from others who speak on the same topic?

4. How did the speaker make key points? (For example, did he or she tell a story, show graphs or charts, use persuasion or emotion, use facts and figures, or employ humor?)

5. What question(s) would you like to ask the speaker about his or her thoughts on the subject?

6. What do you think the speaker's notes looked like as he or she was preparing the talk or presentation? include?

7. Did the speaker leave out something you feel was important to

8. Write an analysis of this speaker's thoughts using examples from the talk to substantiate your thoughts.

- In what ways are your thoughts different or similar to the thoughts of the speaker?

- How might the speaker have made his or her thinking more clear?

9. In what way did the speaker demonstrate the thinking of experts in his or her field? (Lent \& Voigt, 2018).

The strategies in the disciplinary literacy shown in Table 2 are deeper and more oriented to the critical thinking development, what is in high demand in the modern society compared to the generic skills strategies (Evers, 2011). 
Table 2

\section{Comparison of generic reading strategies and discipline-specific reading}

\section{strategies}

\begin{tabular}{|l|l|}
\hline \multicolumn{1}{|c|}{ Generic Reading Strategies } & \multicolumn{1}{c|}{ Discipline-Specific Reading Strategies } \\
\hline Monitor comprehension & Build prior knowledge \\
Pre-read & Build specialized vocabulary \\
Set goals & Learn to deconstruct complex sentences \\
Think about what one already knows & Use knowledge of text structures and genres to \\
Ask questions & predict main and subordinate ideas \\
Make predictions & Map graphic (and mathematical) representations \\
Test predictions against the text & against explanations in the text \\
Re-read & Pose discipline relevant questions \\
Summarize & Compare claims and propositions across texts \\
& Use norms for reasoning within the discipline (i.e. \\
& what counts as evidence) to evaluate claims \\
\hline
\end{tabular}

The reasons for developing Disciplinary literacy are suggested as a wide area of implication. Disciplinary literacy might be motivating because it fulfils the needs and desires, as the modern techniques used at class for activating DL encourage students to be engaged more into the activity they fulfil. DL can also create a lot of opportunities for collaborative work and peer interaction. DL may quench students need to meet challenges, to understand, and seek affiliations (Shanahan \& Shanahan, 2014).

Conclusions. The present study was designed to determine the necessity of defining disciplinary learning. The first question in the study was to identify the interpreting of disciplinary literacy in the modern education system. The second question sought to determine the importance of disciplinary literacy.

And another question was focused on the theoretical frame of defining the structure of disciplinary literacy. This research contributes to disciplinary literacy literature by demonstrating the importance of disciplinary literacy in the context of modern educational requirements. Many studies have reported on the defined terms of disciplinary literacy and presenting the classified identification of the types of disciplinary literacy within different disciplines, distinguished by different authors at different time. At the same time, modern requirements to the models in teaching according to the demands of time make the necessity and possibility to adopt the disciplinary literacy to the definite educational environment considering the exact discipline we work with. This will allow us to develop a new set of skills in the framework of the discipline we teach, and to develop proper strategies for teaching.

Consistent with recent research advocating the identifying disciplinary literacy, our findings indicate that this is a process of defining the specific professional component which should be developed deeply for the further educational process. The main idea of the construct of disciplinary literacy, that the generic skills, such as reading, writing, inquiring and collaboration work together to help develop the specific another component - that is target professional one. 
Our findings highlight the main identifications of disciplinary literacy in the light of a number of disciplines. We also reported on the model of development literacy starting from basic to the highest, disciplinary one in reading. And we reviewed the differences between the deeper learning and disciplinary literacy.

We are not yet in a position to offer the unique classification of disciplinary literacy, which would fit the modern requirements in education. This construct may vary depending on the specific subject, we teach. The development of this term is comparatively new and there are a lot of definitions and descriptions of the components of the complete set. This review provides implications for identification and integrating the relevant literacy practices which promote effective understanding, analysis and evaluation of texts in their disciplines and practices for further specific and professional use.

Different ways of learning present one of the main limitations of this study. The definite relationships are present between the types of disciplinary literacy and different disciplines in the educational process.

Future work is needed to develop the specific set of skills of disciplinary literacy for the necessary discipline questionnaire about needs of learners and providing content and more developed strategies for critical thinking and usage in different ways: reading, writing, inquiry, and collaboration.

\section{REFERENCES}

Airey, J. (2011). The disciplinary literacy discussion matrix: A heuristic tool for initiating collaboration in higher education. Across the disciplines, 8 (3), $\mathrm{n} 3$.

Archibald, S., Coggshall, J. G., Croft, A., \& Goe, L. (2011). High-Quality Professional Development for All Teachers: Effectively Allocating Resources. Research \& Policy Brief. National Comprehensive Center for Teacher Quality.

Evers, T. (2011). Common core state standards for literacy in all subjects. Madison, WI.

Fang, Z. (2012). Language correlates of disciplinary literacy. Topics in Language Disorders, 32 (1), 19-34.

Grigg, W., Donahue, P., \& Dion, G. (2007). The Nation's Report Card [TM ]: 12th-Grade Reading and M athematics, 2005. NCES 2007-468. National Center for Education Statistics.

Halliday, M. A. K., Matthiessen, C., \& Halliday, M. (2014). An introduction to functional grammar. Routledge.

Hillman, A. M. (2014). A literature review on disciplinary literacy. Journal of Adolescent \& Adult Literacy, 57 (5), 397-406.

International Literacy Association. (2017). Content area and disciplinary literacy: Strategies and frameworks [Literacy leadership brief]. Newark, DE: Author.

Kirsch, I., de Jong, J., Lafontaine, D., M cQueen, J., M endelovits, J., \& M onseur, C. (2002). Reading for change. Performance and engagement across countries. Recuperado el, 8.

Lent, R. C. (2015). This is disciplinary literacy: Reading, writing, thinking, and doing... content area by content area. Corwin Press.

Lent, R. C., \& Voigt, M. M. (2018). Disciplinary Literacy in Action: How to Create and Sustain a School-Wide Culture of Deep Reading, Writing, and Thinking. Corwin Press. 
McConachie, S. M., \& Petrosky, A. R. (2010). Engaging content teachers in literacy development. Content Matters: A disciplinary literacy approach to improving students learning, 1-14, p. 6.

Moje, E. B. (2007). Developing socially just subject-matter instruction: A review of the literature on disciplinary literacy teaching. Review of Research in Education, 31 (1), 1-44.

Shanahan, T., \& Shanahan, C. (2008). Teaching Disciplinary Literacy to Adolescents: Rethinking Content-Area Literacy. Harvard Educational Review, 78 (1), 40-59. https://doi.org/10.17763/haer.78.1.v62444321p602101.

Shanahan, T., \& Shanahan, C. (2012). What is disciplinary literacy and why does it matter? Topics in language disorders, 32 (1), 7-18.

Shanahan, C., \& Shanahan, T. (2014). The implications of disciplinary literacy. Journal of Adolescent \& Adult Literacy, 57 (8), 628-631.

Spires, H. A., Kerkhoff, S. N., Graham, A. C., Thompson, I., \& Lee, J. K. (2018). Operationalizing and validating disciplinary literacy in secondary education. Reading and writing, 31 (6), 1401-1434.

Zygouris-Coe, V. (2012). Disciplinary literacy and the common core state standards. Topics in Language Disorders, 32 (1), 35-50.

\section{АНОТАЦІЯ}

Ляшенко Ірина. Розвиток дисциплінарної грамотності як основний стандарт освіти.

Сучасні вимоги до якості освіти вимагають постійного вдосконалення підходів до пошуку оптимального навчання, оскільки останніми роками спостерігається тенденція до розвитку комунікації та зниження якості засвоєння матеріалу студентами. Сучасна освіта зосереджується на розвиткові загальних навичок, але з іншого боку, сучасна система освіти не підкреслює розвиток спеціальних навичок, які спрямовані на базові навички. Метою даного дослідження було вивчення концепції дисциплінарної грамотності, яка покликана поглибити процес навчання, щоб гармонізувати роботу всіх спільних компонентів з потребою в конкретних навичках.

У статті зроблено огляд літератури з основних визначень дисциплінарної грамотності та інтерпретовано змістові компоненти цієї ідеї по відношенню до дисципліни.

Для досягнення поставленої мети використовувалися методики огляду літератури: підтвердження гіпотези та виконання дослідницьких завдань, використовувався комплекс сучасних теоретичних методів дослідження та підходів: аналіз, синтез, індукція, дедукція, систематизація, порівняння, узагальнення, яке дозволило розробити наукові джерела, визначити сутність та особливості аналізу потреб, обгрунтувати переваги й недоліки.

Дане дослідження повідомляє про структуроване визначення дисциплінарної грамотності, що представляє різні інтерпретації та компромісний аналіз. Це дослідження також визначило причини необхідності забезпечення дисциплінарної грамотності. Ще одним доречним моментом $\epsilon$ mе, що стаття пропонує сфреру впливу на дисциплінарну грамотність. У цій статті також розглядаються основні стратегії розвитку дисциплінарної грамотності.

Огляд літератури представив модель розвитку дисциплінарної грамотності. Вона виділяється як перехід від базових навичок до вищої ієрархії до дисциплінарної грамотності. Проаналізовано відмінності між більш глибоким навчанням $i$ дисциплінарною грамотністю. 
Відповідно до недавніх досліджень, які виступають за виявлення дисциплінарної грамотності, наші висновки показують, що че процес визначення специфічної складової дисциплінарної грамотності, яка має бути цільовою точкою для конкретної освіти. Проте, ми ще не готові запропонувати унікальну класифрікацію дисциплінарної грамотності, яка відповідатиме кожній профресійній дисципліні.

Ключові слова: грамотність, дисциплінарна грамотність, загальні навички, розвиток спеціальних навичок, стратегій розвитку дисциплінарної грамотності.

\section{PEЗЮME}

Ляшенко Ирина. Развитие дисциплинарной грамотности как основной стандарт образования.

Современные требования к качеству образования требуют постоянного совершенствования подходов к поискам оптимального обучения, поскольку последние годы отмечается растущая тенденция развития коммуникации и снижения качества усвоения материала у студентов. Современное обучение ориентировано на развитие общих навыков, но, с другой стороны, современная система образования не ставит ударение на развитии специальных профрессиональных навыков, на которые и направлены основные умения. В данной работе рассматривается анализ понятия дисциплинарной грамотности, которая призвана углубить процесс обучения с целью гармоничной работы всех общих компонентов на потребности целевых специфических навыков. Работа дает литературный обзор дисциплинарной грамотности в процессе обучения.

Ключевые слова: дисциплинарная грамотность, грамотность, развитие специальных навыков, общих навыков, стратегий развития дисциплинарной грамотности.

УДК 37.013 .43

Людмила Пономаренко

Сумський державний педагогічний

університет імені А.С. Макаренка

ORCID ID 0000-0002-4591-563X

DOI 10.24139/2312-5993/2019.07/090-099

\section{СОЦІАЛЬНЕ ПАРТНЕРСТВО ЯК СПОСІБ УДОСКОНАЛЕННЯ СИСТЕМИ НАДАННЯ СОЦІАЛЬНИХ ПОСЛУГ НА РІВНІ ГРОМАДИ}

Стаття присвячена вивченню змісту поняття «сочіальне партнерство», а також визначенню сочіального партнерства як способу вдосконалення системи надання соціальних послуг на рівні громади. Соціальне партнерство розглядається як організована співпраця між різними соціальними інститутами, включаючи державні і громадянські організації, а також комерційний сектор. Представлено принципи та проблеми становлення соціального партнерства у сфері надання соціальних послуг на рівні громади. Висвітлено переваги від співпраці державних та громадських організацій у сфері надання соціальних послуг на рівні громади.

Ключові слова: сочіальне партнерство, сочіальний захист, громадські організації, децентралізація, територіальна громада, комерційний сектор, державні соціальні інститути, сочіальні послуги. 